\title{
Travel and Experience in Early Modern English Literature
}



Travel and Experience in Early Modern English Literature 
Melanie Ord 
travel and experience in early modern english literature

Copyright $\odot$ Melanie Ord, 2008.

All rights reserved. No part of this book may be used or reproduced in any manner whatsoever without written permission except in the case of brief quotations embodied in critical articles or reviews.

First published in 2008 by

PALGRAVE MACMILLAN ${ }^{\text {TM }}$

175 Fifth Avenue, New York, N.Y. 10010 and

Houndmills, Basingstoke, Hampshire, England RG21 6XS.

Companies and representatives throughout the world.

PALGRAVE MACMILLAN is the global academic imprint of the Palgrave

Macmillan division of St. Martin's Press, LLC and of Palgrave Macmillan Ltd.

Macmillan ${ }^{\circledR}$ is a registered trademark in the United States, United Kingdom

and other countries. Palgrave is a registered trademark in the European

Union and other countries.

ISBN-13: 978-0-230-60298-4

ISBN-10: 0-230-60298-3

Library of Congress Cataloging-in-Publication Data

Ord, Melanie.

Travel and experience in early modern English literature / Melanie

Ord.

p. cm.

Includes index.

ISBN 0-230-60298-3 (alk. paper)

1. English literature-Early modern, 1500-1700-History and criticism. 2. Travel in literature. 3.

Experience in literature. 4. Knowledge, Theory of, in literature. I. Title.

PR428.T73073 2008

820.9'3209031-dc22

2007048030

A catalogue record of the book is available from the British Library.

Design by Scribe Inc.

First Edition: August 2008

10987654321

Printed in the United States of America. 
For my parents. And for Nick. 


\section{Contents}

List of Figures

Acknowledgments

Introduction

1 Travel and Education in Roger Ascham's The Scholemaster (1570)

2 Travel and Prodigality in John Lyly's Euphues (1578 and 1580)

3 The New Science and Travel Method

4 Textual experience in Thomas Coryat's Crudities (1611): Reading, Writing, Travelling

5 Travelling through Texts: John Dunton's A Voyage Round the World (1691) and the Art of Digression

Postscript

Works Cited

Index 


\section{Figures}

4.1 Image of Thomas Coryat superimposed onto a print of the Great Tun at Heidelberg; from Coryats Crudities (1611). Reproduced with the permission of the Brotherton Collection, Leeds University Library.

4.2 Picture of Coryat greeting a Venetian courtesan [misidentified as "Margarita Emiliana"]. Reproduced with the permission of the Brotherton Collection, Leeds University Library.

5.1 The frontispiece to Coryats Crudities (1611). Reproduced with the permission of the Brotherton Collection, Leeds University Library.

5.2 Frontispiece to John Dunton's Voyage Round the World (1691). Reproduced with the permission of Leeds University Library.

$<\sim ? \sim[N B$ : The cover image shows two travellers to Lake Averno, near Naples, printed in George Sandys, A Relation of a Journey, 2nd ed. (1621). The Sibyl's cave is to the left of the picture, and the ruins of Apollo's Temple to the right. This is reproduced with the permission of the Brotherton Collection, Leeds University Library.>

\section{Acknowledgments}

I have accumulated many debts during the course of writing this book, and it is my pleasure to acknowledge some of them here. Chapters 1, 2, and 4 started life as part of my $\mathrm{PhD}$ dissertation, entitled "Narrative Self-Presentation in English Representations of Italy, 15701611," at the University of Leeds. I am grateful to Michael Brennan and David Lindley for their generous supervision: to Michael for reading every draft of every chapter and to David for insisting I sharpen my thinking and shorten my sentences. It became clear by the time I submitted this thesis in 2001 that it would not easily lend itself to publication as a book, and it took a long time for this project to take its present form; I am grateful to Jonathan Bate, Elizabeth Heale, Ralph Pite, and Jenny Richards, among others, for their help and advice during that time.

Since its early days, my work has benefited from generous financial support. My dissertation was funded by the British Academy. Research for Chapter 3 of this book was aided by a British Academy Small Research Grant in 2005. And the Arts and Humanities Research Council (AHRC) provided me with research leave in 2007, which-together with 
institutional leave from the Department of English at University of the West of England, Bristol—gave me the time and space to finish this book.

PLEASE MOVE THIS PARAGRAPH TO THE NEXT PAGE, IN BETWEEN THE CHAPTER BEGINNING ‘CHAPTER 1 OF THIS BOOK...’ AND THAT BEGINNING 'AT PALGRAVE I WISH TO THANK...'. I would like to thank staff at the British Library, London; the Bodleian Library, Oxford; the Arts and Social Sciences Library, University of Bristol (in particular Special Collections and especially Michael Richardson); the Brotherton Library, University of Leeds (in particular Special Collections and especially Oliver Pickering); and the St. Matthias Library at the University of the West of England (especially Graham Brown, who has cheerfully processed a huge number of inter-library loan requests over the past few years).

I am fortunate to work with such supportive colleagues at UWE and would like to extend my thanks to those who shouldered extra responsibilities so that I could take time off from teaching to finish this project (particularly to Charlie Butler for coordinating the module "Literature and the Renaissance" in my absence). I am especially thankful for the friendship of Lene Petersen and Kerry Sinanan . I owe a debt of gratitude to the following scholars, who gave up their time to read draft versions of chapters and provided many suggestions which have helped to make this a better book: Katharine Craik, Leah Knight, Natalie Kaoukji, Shaun Regan, and Kerry Sinanan. I also wish to thank the following friends and colleagues, for many different reasons: Richard Chamberlain, Fred Curtis, Lesel Dawson, Jo Duffy, Ian Fisher, Scott Fraser, Elizabeth Heale, Rosanne Jacques, Andrew McRae, Mike Pincombe, Su Patil, Jenny Richards, Victoria Stewart, Caroline Sumpter, and Deryn Rees-Jones.

I have presented parts of this book at conferences held in Bristol, Glasgow, Leicester, London, Miami, Newcastle, Oxford, Reading, Sherbrooke (Canada), and Wolverhampton 
and am grateful for the feedback I received from scholars on those occasions. I wish to thank the Schools of English at the Universities of Leeds, Liverpool, and the West of England, Bristol, for financial assistance to attend these conferences.

Chapter 1 of this book first appeared, in altered form, as an article entitled "Classical and Contemporary Italy in Roger Ascham's The Scholemaster (1570)" (Renaissance Studies 16: 2 (2002): 202-16), and I am grateful to Blackwell publishing for granting permission to reprint this material. A few sentences from a chapter entitled "Returning from Venice to England: Sir Henry Wotton as Diplomat, Pedagogue, and Cultural Connoisseur" in Borders and Travellers in Early Modern Europe, edited by Tom Betteridge (2007), appear in the introduction to this monograph, and some passages from an essay entitled "Provincial Identification and the Struggle over Representation in Thomas Coryat's Crudities (1611)" in Archipelagic Identities: Literature and Identity in the Atlantic Archipelago, 1550-1800, edited by Philip Schwyzer and Simon Mealor (2004), are reproduced in Chapter 4. I am grateful to Ashgate Publishing for permission to print them here.

THE CHAPTER BEGINNING 'I WOULD LIKE TO THANK STAFF...'

\section{BELONGS HERE.}

At Palgrave I wish to thank Farideh Koohi-Kamali, Julia Cohen, Brigitte Shull, and Kristy Lilas. I am also most grateful to the anonymous readers of my manuscript for their queries, comments, and suggestions, which helped to give further shape to the project as a whole.

Special thanks go to my parents, Maureen and Brian Ord, and to my husband, Nick Bandu, for their unflagging support, love, and encouragement.

Travel and Experience in Early Modern English Literature is funded by < ? TN: insert AHRC logo>. 